\title{
TEACHING COLLOCATION USING LEXICAL APPROACH AS USED IN MADE FRIDA YULIA'S VOCABULARY: LEXICALLY-BASED SECOND THOUSANDS WORDS OF GENERAL SERVICE LIST BOOK
}

\author{
Petrus Chandra
}

\begin{abstract}
.
This research was to give insight to English teachers and practitioners who had the same problem faced by the writer and his students especially dealing with the lack of collocation. Moreover, this research inspired particularly those who involved in teaching practices for how to improve their professionalism by implementing Lexical-Based Approach in class activities and to find the solution and hindrances for a better teaching technique in the future. For students who had problems in collocation, this Lexical-Based Approach as used in Made Frida Yulia's Vocabulary: Lexically-Based Second Thousand Words of General Service List book might improve the awareness toward lexical phrases, chunks and collocations. For teachers and practitioners who want to use this Lexical-Based Approach in the future could use bilingual explanation that is needed for Indonesian students rather than monolingual explanation in English, try to create a good note taking habit for lexical phrases as soon as possible, and use vivid pictures or audio visuals to kill the boredom of the students.
\end{abstract}

Keywords: Collocation, Contrived Learning, Incidental Learning, Lexis

The rationale of this study was under the argument that Lexical-Based Approach as used in Made Frida Yulia's Vocabulary: Lexically-Based Second Thousand Words of General Service List book might improve his students' collocation production in their writing assignment. Since this theory of Lexical Approach as proposed by Michael Lewis had a belief that the building blocks of language learning and communication are not grammar, functions, or notions but lexis, words and word combinations (collocation). These lexical phrases or chunks then became the raw data in students' mental lexicon which later on they might be able to produce and use them for both spoken and written discourse.

This Lexical-Based Approach inspired Kweldju (1997) to introduce LexicalBased Language Teaching, which had been made relevant to Indonesian conditions. It emerged as a solution to two main problems of Indonesian students learning English in that it might improve students' vocabulary size as well as their mastery of collocations. This was so since lexical-based materials raised students' awareness of the existence of chunks and of the fact that learning vocabulary was more than just learning individual words but collocation in a broader sense. 
Made Frida Yulia (2005) stated that Lexical-Based Approach held the view that facilitating learning was more important than teaching itself. It thus equipped learners with the ability to learn vocabulary continually, either with or without instruction. This skill fulfilled one of the IGCSE syllabus goals that learners would be independent learners that they might be able to further their study in college or university. Hence, these learners were to be involved in four different activities that foster vocabulary acquisition. They were wide reading, learning individual words and lexico-grammatical units, improving word learning strategies, and increasing word consciousness.

The writer then followed the two elements suggested Made Frida Yulia, they were contrived learning and incidental learning. In contrived learning section, it employed reading passages which provided opportunities for students to observe the lexico-grammatical units and how they were used in real contexts. The passages gave extensive exposure to words, expressions, and structures. Following the passage were chunk identification, completion, matching, word family identification, and rewriting exercises.

Meanwhile, the incidental learning section required students to read extensively, so as to obtain as much exposure to language as possible. Students were to do library researching guided by certain sub-lists. They were assigned to find information from real language use (i.e., their reading) about the co-texts of the unknown lexical items on the sub-lists, their pronunciation and meaning. The findings were to be recorded in a notebook.

The writer took two materials along with the exercises from the book (Vocabulary: Lexically-Based Second Thousand Words of General Service List, Made Frida Yulia, 2005) for two weeks. He had given Pre and Post Test to see whether there was any improvement in students' collocation production in their writing assignments after implementing this Lexical-Based Language teaching technique. He took questionnaires from the students and made the teaching journal to record if there were any hindrances or problems while doing this technique. With reference to the background of the study, the writer formulated the research questions as follows: 
(1). Could Lexical-Based Approach used in Made Frida Yulia's Vocabulary: Lexically-Based Second

Thousand Words of General Service List Book improve the students' collocation production?

(2). Which collocation improved most: Adjective-Noun or Adverb-Verb combination?

(3). What are the students' perceptions about the teaching technique and the materials?

In line with the problems stated above, the purposes of this study were to know whether Lexical-Based Approach used in Made Frida Yulia's Vocabulary: Lexically-Based Second Thousand Words of General Service List book could improve the students' collocation production in their written discourse and to improve the teacher's teaching technique through Lexical-Based Approach.

This research was to give insight to English teachers and practitioners who had the same problem faced by the writer and his students especially dealing with the lack of collocation. Moreover, this study inspired particularly those who involved in teaching practices for how to improve their professionalism by implementing Lexical-Based Approach in class activities and to find the solution and hindrances for a better teaching technique in the future.

Vocabulary is the most vital language component that enables the students to master the language. In other words, the students must learn many thousands of words if they wish to be able to master the language. This view was well supported by Rubin (1994:79) who asserted: 'one cannot speak, understand, read, or write a foreign language without knowing a lot of words. Therefore, vocabulary learning was the heart of mastering a foreign language'.

Moreover, the importance of vocabulary learning was also supported by the linguist David Wilkins who said, 'Without grammar very little can be conveyed, without vocabulary nothing can be conveyed'. He summed up his view to the students in this recent course book (Dellar. H. and Hocking. D., Innovations, LTP): "If you spend most of your time studying grammar, your English will not improve very much. You will see most improvement if you learn more words and 
expressions. You can say very little with grammar, but you can say almost anything with words!" Based on his statement, we might be sure that learning vocabulary was essential part of teaching any languages in this world without vocabulary teaching, nothing could be learned.

Since the vocabulary was really important in communication. All English teachers should give special attention to allocate some of the teaching time to give explicit vocabulary exercise to their students. Due to the writer own experience in teaching writing, most of his students said that the main cause of their failure in writing assignments was their lack of vocabulary and collocational competence. Instead of using the words appropriately, they used longer sentences and made confusing to the reader.

Lexical approach was a belief that lexicon plays a central role in shaping the teaching goals, the types of syllabus adopted, teaching methodology and techniques used in the classroom. It was a belief that building blocks of language learning and communication are not grammar, functions, notions, or some other unit of planning and teaching but lexis, that was, words and word combinations (Richards, J. \& Rodgers, T. 2007).

Michael Lewis (1993) in his book Lexical Approach said, "Language consists of grammaticalized lexis not lexicalized grammar". It meant that lexis was the core or heart of language not grammar. In other words, he challenged the traditional view that language competence consisted of having a foundation of grammatical structures into which we slotted individual words was no longer valid. Instead, he said that we stored a huge assortment of memorized words, phrases and collocations, along with their associated 'grammar'. Then, when it came to production of our oral or written discourse, we could select from our stored phrases or chunks in our mental lexicon and then we fine-tuned the grammar not the other way around.

This lexical approach stressed the importance for second language learners to put lexis, words or word combinations, as the prime goal in teaching learning process and not the grammar. It also pointed out that conscious-raising activities such as identifying, matching, fill-in-gap, or making sentences from those chunks 
that the students found would bring great benefit for the students later on to increase their awareness of and sensitivity to the lexical items.

In related to the researcher situation, this lexical approach supported the plan, he was going to do. Since these conscious-raising activities were the central strategy of lexical approach, he believed that accurate noticing and memorizing lexical chunks would help the students acquired the language better and faster. These conscious-raising activities would also convert the input into intake in their second language acquisition process which later on the students might be able to produce them in oral and written discourse fluently and appropriately.

Pawley and Syder (1983) distinguished clearly between what was memorized and what was lexicalized, they said, "Not all sequences memorized by individual speakers were lexicalized. What made an expression a lexical item, what made it part of a speech community's common dictionary, was firstly, that the meaning of the expression was not (totally) predictable from its form. Secondly, that it behaved as a minimal unit for certain syntactic purposes, and third that it was a social institution. This last characteristic was sometimes overlooked, but was basic to the distinction between lexicalized and non-lexicalized sequence".

For them, lexical items were such these:

- Meaning was not totally predictable from form.

- Each was a minimal unit for certain syntactic purposes.

- Each was a social institution.

Meaning was not totally predictable from form. It meant that lexical items were neither more nor less than individual words so it was no surprise that the fundamentally arbitrary nature of the sign must apply.

For example every teacher was familiar with the difficulty when a student asked "Can you say ...?" and the teacher replied, "Well, you could say that, but you wouldn't". Then the student asked, "Why? " Only to receive unsatisfactory answer “It just doesn't sound right". This fact was indispensable for all language teachers and showed that the most fundamental principle of linguistics was the arbitrariness of the sign. A particular thing was called a pen in English, while another thing was 
called a book, but we could not usefully ask why these particular words were used for these particular objects.

Each was a minimal unit for certain syntactic purposes. Language could be sub-divided in many ways - sentences, turns, morphemes, phonemes. For different purposes different items constituted minimal units. For instance, a relative could be close, near or distant while a friend could be close, but neither distant nor near, although a close friend might be one of your nearest and dearest.

Each was a social institution. Language was a social phenomenon, socially rather than individually defined. Many sentences which were possible if generated by native speaker could immediately be recognized as improbable. There was a vast difference between what we could say and what we did say. It appeared that of all the sentences which might be produced by a native speaker, some occurred with much greater frequency than we might expect while we were certain that some other possible sequences would never occur unless a linguist produced them for the purpose of demonstrating their implausibility or impossibility.

Michael McCarthy (2005) in his book "English Collocation in Use" stated, "Collocation is a group of words or word combinations that are often used together". These combinations were not based on rules of grammar but on traditions of use by native speakers. These combinations of word just sounded "right or natural" to native speakers while others might sound "wrong or unnatural" for example; instead of saying 'quick cars, quick foods', we say 'fast cars or fast foods'.

Learning collocation was very important to the students because it could help them to produce the language in more natural and accurate way. Teachers probably understood what the students meant if they talked about 'making your homework' where we should say 'doing your homework' or 'my uncle is a very high man' where we should say 'My uncle is a very tall man'. These wrong or unnatural discourse might cause confusing and misunderstanding. Did the student mean that his uncle is two meters tall or did he mean that his uncle has a high position in government or business?

Moreover, learning collocation would also help the students to boost their English vocabulary mastery. It gave them alternative ways of saying something, 
which were more colorful, expressive, and precise. Instead of repeating the word like 'It was very cold and very dark', they could say 'It was bitterly cold and pitch dark'.

Hill (in Lewis, M., 2000: 63) argued that it was the medium-strength collocations which were most important for the ESL classroom. Jimmie Hill offered the following schema for pointing out collocations to students:

- Unique collocations. For example: foot the bill; shrug your shoulders. (These were unique because foot (as a verb) and shrug were not used with any other nouns)

- Strong collocations. For example: trenchant criticism, rancid butter. (There were other things that could be trenchant or rancid, but very few)

- Weak collocations. For example: a tall woman, a red shirt, an expensive car, a loud noise. (These combinations are entirely predictable to most students and not worth focusing on)

- Medium-strength collocations. For example: hold a conversation, a major operation, expensive tastes, a loud shirt. (Those words such as expensive and loud could form both weak and medium-strength collocations)

Jane Conzett taught as in instructor in an Intensive English Program (IEP) in the United States. She taught reading and writing classes. She described that the goal of most IEPs was to improve students' ability to use English for academic and professional purposes, most often in preparation for academic tasks in American colleges and universities. The approach to curriculum was frequently Content-Based Approach with integrated skills which had similarity with Cambridge IGCSE syllabus.

She reported that her discovery and understanding of collocation resulted from her frustration with vocabulary study in her classroom. Despite careful, contextualized study of vocabulary in her reading and writing classes, her students often used their new vocabulary incorrectly when they moved from receptive to productive language.

As she struggled to remedy what was not working in her classes, she stumbled upon the nation of collocation, a word that she never heard of before. Since then, she 
changed her approach in teaching vocabulary for her reading and writing classes to Lexical-Based Approach which had resulted in more accurate language production by her students.

As do many American IEPs today, this program taught reading and writing as an integrated course. Students read articles on texts, often grouped thematically around a particular content area such as "work and careers" on "society and aging" and then responded to the readings in writing, using a variety of discourse types. This was also similar with IGCSE materials. Students were given articles or texts, grouped thematically around a particular content area such as 'Health or Fitness' then they responded to the text in writing assignment such as a letter to the mayor of the city about pollution.

The problem came up, when she found some sentences that were produced by her students such as:

- Be careful. That snake is toxic

- We will sever this class because it is too large

- A Ferrari is a very potent car

Her usual response to production errors at this type was to give her student partial or half credit because they had obviously understood the meaning of the words despite the awkward sentences. When a student asked, But doesn't toxic mean poisonous? She would give a response a long the lines of, Well, yes, but we don't usually use it that way, which left both of them feeling frustrated and dissatisfied. This condition also happened at Gloria Senior High School Grade Ten students which the researcher was teaching; most of them produced awkward sentences and wrong choice of word in their writing assignments due to their lack of collocational competence.

To overcome this condition, Jane Conzett proposed several ways to make students aware of collocation which were adopted and used by the researcher while doing his research, such as:

1. Teach students the word 'collocation'

It was helpful to remind the students that just like their native language, the English language had some words that went together and some that did not. The 
researcher as the teacher also taught the word collocation explicitly to raise his students' awareness toward this term.

2. Adapt books to include collocations

Modifying and adapting existing books with collocation was a good solution. Students could make notations about frequent collocations next to the word lists. However, the researcher directly used Made Frida Yulia's book that systematically had been designed for Lexical-Based language teaching technique.

3. Context and collocation notebooks

Jane Conzett gave examples from Goodman's Advancing Vocabulary Skills, a book for native speakers and learners which they used in their advanced reading and writing class.

Word Special context? Collocations

Facetious (adj) (flippant - often negative) Noun: a remark

Example: I wish Bill would stop making facetious remarks.

She used a stenographer's notebook because it was portable for recording vocabulary with ready-made two columns that were ideally suited to record context and collocation in their respective places, following the initial word entry and definition. In this case, the researcher used different format of a notebook. He just followed the notebook format suggested by Made Yulia.. (see Appendix Three)

4. Train students to observe and note collocations in reading

Because ESL reading and writing books were commonly organized thematically around subjects such as 'the workplace' or 'prisons' this could present an ideal opportunity to train students to observe collocations in their reading, and to note and use these expressions in their writing.

The most important thing for teachers was to shift the students' focus away from individual words to chunks of language. These chunks would improve the fluency and accuracy of the English students' production skills. It could be accomplished by simply calling students' attention to the collocations in the readings, studying them as a part of a vocabulary list, and repeating and 
reinforcing them in writing assignment. In this case, the researcher did the same thing for his students.

5. Collocating in writing

As writing was frequently taught integrated with reading in many IEPs, the same like in IGCSEs, teachers could review with their students a list of collocations and expressions that were important from the reading to accurately expressing the ideas relevant to the topic in their writing assignments.

Alternatively, for a writing assignment which did not follow a reading selection, teachers could quickly prepare a short list of common collocations and phrases used in the context relevant to that assignment as a pre-writing exercise. In this case, the researcher did the same thing by giving his students sample collocation in context that relevant for the students' writing assignment.

6. 'Look it up twice'

Students could improve the accuracy of their collocation by decoding and encoding using their bilingual dictionary. The researcher allowed his students to open their dictionary for help.

This report by Jane Conzett, inspired the researcher to use some of the techniques suggested by her, such as the way she taught collocation explicitly in class, the use of lexical notebook and the training of her students to have awareness toward collocation in reading text that they might be able to produce them later on their writing assignment. The different things from this report with the researcher's study were that the researcher used already made materials from Made Frida Yulia's book that systematically had been designed in such a way using Lexical-Based Approach that he might follow easily. The next different thing was that the format of the lexical notebook suggested by Made Frida Yulia was different from the format used by Jane Conzett. 


\section{Methodology Research Design}

The writer used a reflective study which primarily focused its attention on the effect of Lexical-Based Approach toward the students' collocation production in their written discourse. The writer compared the frequency of Lexical Phrases and Collocation (Adjective-Noun and Adverb-Verb combination) between Pre and Post Test of his students' writing assignments.

\section{Participants}

The participants were twenty four students of Gloria Senior High School Grade Ten. After the vocabulary level test, the writer found that the participants had different level of English vocabulary proficiency. There were 9 students (37.5\%) below 2000 words level, 4 students (17\%) exactly at 2000 words level, and 11 students $(46.5 \%)$ above 2000 words level test. However, they had the same problem with collocation.

\section{Research Instruments}

The instruments of this study were firstly the writer himself, as it was called a reflective study, the interpretation of the data found would depend solely on the researcher's skills, ability and competence in analyzing the data. The second instruments were the reading passages from Made Frida Yulia's Vocabulary: Lexically-Based Second Thousand Words of General Service List book as used by the researcher to raise the students' awareness toward lexical phrases and collocation. Finally, the third instruments were the students' writing assignments from Pre and Post Test. The writer used them to find out the frequency of lexical phrases and collocation produced by the students.

\section{Source of Data}

The source of data that the writer had taken were the students' descriptive essay in order to calculate the frequency of Adjective-Noun combination in week one and students' summary of the reading passage in order to calculate the frequency of Adverb-Verb combination in week two, students' Pre-Post test, questionnaires, students' lexical notebook and finally the teacher's teaching journal for the reflection. 


\section{Data Collection Procedures}

To get the appropriate data, the writer used these Lesson Plans below:

\section{Week One}

1. On the $1^{\text {st }}$ Meeting (45 minutes), the teacher gave short explanation for what going to happen on the coming class and a Pre-Test for 30 minutes for the students to do.

2. On the $2^{\text {nd }}$ Meeting (90 minutes), the teacher gave explanation about collocation and some examples on the slide then asked the students to read the reading passage with the title "The King Grisly Beard" by Brothers Grimm for 30 minutes. After that the teacher helped his students to identify lexical phrases and Adjective-Noun combination from the passage by underlining them. Then, the students did the exercises for 30 minutes and submitted it. Finally, the last 15 minutes, the teacher explained how to do the homework for the next meeting. He asked the students to see the sub-lists and assigned them to find information from real language use (i.e., their reading) about the co-texts of the unknown lexical items on the sub-lists, their pronunciation and meaning. The findings were to be recorded in a notebook and would be checked by the teacher the next meeting. Furthermore, students also recorded other lexical items that were not on the lists, but they might need.

3. On the $3^{\text {rd }}$ Meeting (135 minutes), the teacher took the homework from the students to be checked. The teacher then gave a picture on the slide (see Appendix Twelve) and a sample descriptive essay about the picture. He asked the students to identify Adjective-Noun combination on the sample essay, after that the teacher closed the sample essay and asked the students to make their own descriptive essay based on the same picture using their own words and Adjective-Noun combination as many as they could. Teacher then took the students' essay and gave a Post Test. The last activity, he gave a questionnaire to be filled and interviewed some students about this teaching technique and materials. 


\section{Week Two}

1. On the $1^{\text {st }}$ Meeting (45 minutes), the teacher gave a Pre-Test for 30 minutes for the students. Then, he distributed the new handout with brief explanation about how the second week should run.

2. On the $2^{\text {nd }}$ Meeting ( 90 minutes), Then, he asked the students to read the reading passage with the title "The Twelve Dancing Princesses" by Brothers Grimm for the students to be read in 15 minutes (see Appendix Four). After reading it, the students did the exercises for 30 minutes, and then the teacher discussed the answer together for another 30 minutes.

3. On the $3^{\text {rd }}$ Meeting (135 minutes), the teacher discussed the answer together for another 45 minutes and gave a Post Test. The last activity, he interviewed some students about this teaching technique and materials.

\section{Data Analysis Procedures}

Referring to the research design, the procedure of analyzing the data was as follows:

1. The writer compared the students' vocabulary level test results before and after the treatment. In this case, before week one and at the end of week two. He used the data to see the effect of this teaching technique toward the students' vocabulary proficiency.

2. The writer examined the frequency of his students' collocation and lexical phrases production in their writing assignment results between Pre and Post Test for each week. He used this data to know if there were any differences.

3. The writer gave questionnaires to the students after the treatments (at the end of each week). He used the data to see what the students' opinion toward the teaching technique and the materials they had learned.

4. The writer made the teaching journal to record whatever happened in class in order to find what were the problems faced by the students during implementing this Lexical-Based teaching technique. 


\section{Results}

Table 1

\section{Based on the Pre-Post Test on Students' Writing Assignments}

\begin{tabular}{|c|c|c|c|c|c|c|}
\hline \multicolumn{7}{|c|}{ WEEK ONE } \\
\hline \multirow{2}{*}{ NAME } & \multicolumn{3}{|c|}{$\begin{array}{c}\text { CORRECT ADJECTIVE-NOUN } \\
\text { COMBINATION }\end{array}$} & \multirow{2}{*}{$\begin{array}{c}\text { PRE-POST } \\
\text { TEST } \\
\text { DIFFERENCES }\end{array}$} & \multirow{2}{*}{$\begin{array}{l}\text { LEXICAL } \\
\text { PHRASES }\end{array}$} & \multirow{2}{*}{$\begin{array}{l}\text { VOCABULARY } \\
\text { LEVEL TEST }\end{array}$} \\
\hline & $\begin{array}{l}\text { PRE- } \\
\text { TEST }\end{array}$ & DURING & $\begin{array}{l}\text { POST } \\
\text { TEST }\end{array}$ & & & \\
\hline CARISSA & 6 & 5 & 7 & 1 & $\mathrm{~N}$ & UNDER 2000 \\
\hline CHRISTINA & 3 & 5 & 4 & 1 & $\mathrm{~N}$ & UNDER 2000 \\
\hline CHRISTINE & 1 & 8 & 1 & 0 & $\mathrm{~N}$ & UNDER 2000 \\
\hline FIKA & 1 & 6 & 4 & 3 & $\mathrm{~N}$ & UNDER 2000 \\
\hline IVENA & 3 & 4 & 4 & 1 & $\mathrm{~N}$ & 2000 \\
\hline JESSICA & 13 & 4 & 3 & -10 & $\mathrm{Y}$ & 5000 \\
\hline KARMELITA & 5 & 4 & 1 & -4 & $\mathrm{~N}$ & 3000 \\
\hline LISTYA & 9 & 6 & 8 & -1 & $\mathrm{~N}$ & 3000 \\
\hline MEICY & 4 & 4 & 7 & 3 & $\mathrm{~N}$ & UNDER 2000 \\
\hline MICHELLE & 3 & 4 & 0 & -3 & $\mathrm{~N}$ & UNDER 2000 \\
\hline NATHANIA & 6 & 2 & 6 & 0 & $\mathrm{Y}$ & 5000 \\
\hline SONIA & 3 & 2 & 2 & -1 & $\mathrm{~N}$ & UNDER 2000 \\
\hline ADRIAN & 1 & 4 & 6 & 5 & $\mathrm{~N}$ & 3000 \\
\hline DHARMA & 2 & 2 & 2 & 0 & $\mathrm{~N}$ & UNDER 2000 \\
\hline ELTON & 2 & 1 & 2 & 0 & $\mathrm{~N}$ & UNDER 2000 \\
\hline JAMES & 2 & 6 & 4 & 2 & $\mathrm{Y}$ & UNIVERSITY \\
\hline JORDAN & 2 & 5 & 5 & 3 & $\mathrm{~N}$ & 2000 \\
\hline JUNKO & 5 & 3 & 5 & 0 & $\mathrm{~N}$ & 2000 \\
\hline KEVIN & 13 & 0 & 6 & -7 & $\mathrm{Y}$ & 5000 \\
\hline KWAN & 4 & 4 & 4 & 0 & $\mathrm{~N}$ & 3000 \\
\hline NICO & 0 & 3 & 0 & 0 & $\mathrm{~N}$ & 3000 \\
\hline ROBBY & 5 & 9 & 4 & -1 & $\mathrm{~N}$ & 5000 \\
\hline TIMOTHY & 3 & 4 & 4 & 1 & $\mathrm{~N}$ & 2000 \\
\hline YOSUA & 4 & 2 & 1 & -3 & $\mathrm{~N}$ & 3000 \\
\hline
\end{tabular}

From the table, it could be seen that 9 students or $37.5 \%$ got improvement on the use of correct collocation in their writing assignment. While others around 8 or $33.5 \%$ students still found difficulty in either spelling or word choice. The rest 7 students or $29 \%$ have no improvement or stagnant.

\section{Based on Teacher Journal and Questionnaire}


From the teacher's journal, the writer found that Lexical-Based Approach used in Made Frida Yulia's Vocabulary: Lexically-Based Second Thousand Words of General Service List book in teaching collocation had given positive effects for some students especially in their ability to identify and use correct collocation or lexical phrases in their writing assignment. The responses of the students toward this teaching technique and materials were varied some said that the material was too difficult for them; others said that this technique had improved their vocabulary. Some said that the time was too short and they needed more so that they might learn more while other student said that the technique was boring and confusing.

The analysis was carried out to know whether there was a significant difference between the result of students' collocation production in week one and two in their writing assignment. There were two analyses that had been taken by the writer.

Table 2

Based on the Pre-Post Test on Students' Writing Assignments

\begin{tabular}{|c|c|c|c|c|c|c|c|c|c|}
\hline \multicolumn{10}{|c|}{ WEEK TWO } \\
\hline \multirow[b]{2}{*}{ NAME } & \multicolumn{3}{|c|}{$\begin{array}{c}\text { CORRECT ADVERB-VERB } \\
\text { COMBINATION }\end{array}$} & \multirow{2}{*}{$\begin{array}{c}\text { PRE- } \\
\text { POST } \\
\text { TEST } \\
\text { DIFFE } \\
\text { RENC } \\
\text { ES }\end{array}$} & \multicolumn{2}{|c|}{$\begin{array}{c}\text { CORRECT } \\
\text { ADJECTIVE- } \\
\text { NOUN } \\
\text { COMBINATIO } \\
\mathrm{N}\end{array}$} & \multirow{2}{*}{$\begin{array}{c}\text { PRE- } \\
\text { POST } \\
\text { TEST } \\
\text { DIFFE } \\
\text { RENC } \\
\text { ES } \\
\end{array}$} & \multirow{2}{*}{$\begin{array}{c}\text { LEXICA } \\
\text { L } \\
\text { PHRAS } \\
\text { ES }\end{array}$} & \multirow{2}{*}{$\begin{array}{c}\text { VOCABUL } \\
\text { ARY } \\
\text { LEVEL } \\
\text { TEST } \\
\text { (WEEK } \\
\text { TWO) }\end{array}$} \\
\hline & $\begin{array}{l}\text { PRE- } \\
\text { TEST }\end{array}$ & $\begin{array}{c}\text { DURIN } \\
\mathrm{G}\end{array}$ & $\begin{array}{l}\text { POST } \\
\text { TEST }\end{array}$ & & $\begin{array}{l}\text { PRE- } \\
\text { TEST }\end{array}$ & $\begin{array}{l}\text { POST } \\
\text { TEST }\end{array}$ & & & \\
\hline CARISSA & 1 & Y & 2 & 1 & 4 & 6 & 2 & Y & $\begin{array}{c}\text { UNDER } \\
2000\end{array}$ \\
\hline $\begin{array}{l}\text { CHRISTIN } \\
\text { A }\end{array}$ & 0 & $\mathrm{Y}$ & 0 & 0 & 5 & 5 & 0 & Y & $\begin{array}{c}\text { UNDER } \\
2000 \\
\end{array}$ \\
\hline $\begin{array}{l}\text { CHRISTIN } \\
\text { E }\end{array}$ & 1 & $\mathrm{Y}$ & 0 & -1 & 0 & 0 & 0 & Y & $\begin{array}{c}\text { UNDER } \\
2000 \\
\end{array}$ \\
\hline FIKA & 0 & $\mathrm{Y}$ & 2 & 2 & 9 & 6 & -3 & $\mathrm{Y}$ & 3000 \\
\hline IVENA & 0 & $\mathrm{Y}$ & 3 & 3 & 4 & 2 & -2 & $\mathrm{Y}$ & 3000 \\
\hline JESSICA & 1 & $\mathrm{Y}$ & 2 & 1 & 3 & 6 & 3 & $\mathrm{Y}$ & $\begin{array}{c}\text { UNIVERSIT } \\
\mathrm{Y} \\
\end{array}$ \\
\hline $\begin{array}{l}\text { KARMELI } \\
\text { TA }\end{array}$ & 0 & $\mathrm{Y}$ & 0 & 0 & 7 & 1 & -6 & $\mathrm{~N}$ & $\begin{array}{c}\text { UNDER } \\
2000 \\
\end{array}$ \\
\hline LISTYA & 0 & $\mathrm{Y}$ & 0 & 0 & 7 & 4 & -3 & $\mathrm{Y}$ & $\begin{array}{c}\text { UNIVERSIT } \\
\mathrm{Y} \\
\end{array}$ \\
\hline MEICY & 0 & $\mathrm{Y}$ & 2 & 2 & 4 & 6 & 2 & Y & 2000 \\
\hline $\begin{array}{l}\text { MICHELL } \\
\text { E }\end{array}$ & 0 & $\mathrm{Y}$ & 2 & 2 & 2 & 3 & 1 & $\mathrm{Y}$ & $\begin{array}{c}\text { UNDER } \\
2000 \\
\end{array}$ \\
\hline $\begin{array}{l}\text { NATHANI } \\
\text { A }\end{array}$ & 1 & $\mathrm{Y}$ & 0 & -1 & 7 & 4 & -3 & Y & 5000 \\
\hline SONIA & 1 & $\mathrm{Y}$ & 0 & -1 & 2 & 1 & -1 & $\mathrm{Y}$ & $\begin{array}{c}\text { UNDER } \\
2000 \\
\end{array}$ \\
\hline ADRIAN & 0 & $\mathrm{Y}$ & 0 & 0 & 4 & 7 & 3 & Y & 3000 \\
\hline DHARMA & 0 & Y & 1 & 1 & 0 & 2 & 2 & $\mathrm{~N}$ & $\begin{array}{c}\text { UNDER } \\
2000\end{array}$ \\
\hline
\end{tabular}




\begin{tabular}{|l|c|c|c|c|c|c|c|c|c|} 
ELTON & 0 & $\mathrm{Y}$ & 2 & 2 & 1 & 2 & 1 & $\mathrm{Y}$ & $\begin{array}{c}\text { UNDER } \\
2000\end{array}$ \\
\hline JAMES & 2 & $\mathrm{Y}$ & 0 & -2 & 1 & 5 & 4 & $\mathrm{Y}$ & $\begin{array}{c}\text { UNIVERSIT } \\
\mathrm{Y}\end{array}$ \\
\hline JORDAN & 1 & $\mathrm{Y}$ & 0 & -1 & 2 & 1 & -1 & $\mathrm{Y}$ & $\begin{array}{c}\text { UNDER } \\
2000\end{array}$ \\
\hline JUNKO & 1 & $\mathrm{Y}$ & 3 & 2 & 3 & 1 & -2 & $\mathrm{Y}$ & $\begin{array}{c}\text { UNDER } \\
2000\end{array}$ \\
\hline KEVIN & 0 & $\mathrm{Y}$ & 1 & 1 & 7 & 7 & 0 & $\mathrm{Y}$ & $\begin{array}{c}\text { UNIVERSIT } \\
\mathrm{Y}\end{array}$ \\
\hline KWAN & 0 & $\mathrm{Y}$ & 3 & 3 & 3 & 4 & 1 & $\mathrm{Y}$ & 3000 \\
\hline NICO & 0 & $\mathrm{Y}$ & 1 & 1 & 3 & 9 & 6 & $\mathrm{Y}$ & 3000 \\
\hline ROBBY & 0 & $\mathrm{Y}$ & 0 & 0 & 7 & 4 & -3 & $\mathrm{~N}$ & $\begin{array}{c}\text { UNIVERSIT } \\
\mathrm{Y}\end{array}$ \\
\hline TIMOTHY & 0 & $\mathrm{Y}$ & 0 & 0 & 6 & 4 & -2 & $\mathrm{Y}$ & 5000 \\
\hline YOSUA & 1 & $\mathrm{Y}$ & 0 & -1 & 2 & 0 & -2 & $\mathrm{Y}$ & $\begin{array}{c}\text { UNDER } \\
2000\end{array}$ \\
\hline
\end{tabular}

Table 3

Comparison results between WEEK ONE and TWO

\begin{tabular}{|c|c|c|c|c|c|c|}
\hline \multicolumn{7}{|c|}{ COMPARISON } \\
\hline \multirow[b]{2}{*}{ NAME } & \multicolumn{3}{|c|}{ WEEK 1} & \multicolumn{3}{|c|}{ WEEK 2} \\
\hline & $\begin{array}{l}\text { ADJECTIVE } \\
\text {-NOUN } \\
\text { PRODUCTI } \\
\text { ON }\end{array}$ & $\begin{array}{c}\text { VOCABULA } \\
\text { RY LEVEL } \\
\text { TEST }\end{array}$ & $\begin{array}{c}\text { LEXICA } \\
\text { L } \\
\text { PHRASE } \\
\text { S }\end{array}$ & $\begin{array}{c}\text { ADVERB } \\
\text {-VERB } \\
\text { PRODUC } \\
\text { TION }\end{array}$ & $\begin{array}{c}\text { VOCABULA } \\
\text { RY LEVEL } \\
\text { TEST }\end{array}$ & $\begin{array}{c}\text { LEXICA } \\
\text { L } \\
\text { PHRASE } \\
\text { S }\end{array}$ \\
\hline CARISSA & $\mathrm{Y}$ & UNDER 2000 & $\mathrm{~N}$ & $\mathrm{Y}$ & UNDER 2000 & $\mathrm{Y}$ \\
\hline $\begin{array}{l}\text { CHRISTIN } \\
\text { A }\end{array}$ & Y & UNDER 2000 & $\mathrm{~N}$ & $\mathrm{~N}$ & UNDER 2000 & Y \\
\hline $\begin{array}{l}\text { CHRISTIN } \\
\text { E }\end{array}$ & $\mathrm{N}$ & UNDER 2000 & $\mathrm{~N}$ & $\mathrm{~N}$ & UNDER 2000 & $\mathrm{Y}$ \\
\hline FIKA & $\mathrm{Y}$ & UNDER 2000 & $\mathrm{~N}$ & $\mathrm{Y}$ & 3000 & $\mathrm{Y}$ \\
\hline IVENA & $\mathrm{Y}$ & 2000 & $\mathrm{~N}$ & $\mathrm{Y}$ & 3000 & $\mathrm{Y}$ \\
\hline JESSICA & $\mathrm{N}$ & 5000 & Y & Y & $\begin{array}{c}\text { UNIVERSIT } \\
\mathrm{Y}\end{array}$ & $\mathrm{Y}$ \\
\hline $\begin{array}{l}\text { KARMELI } \\
\text { TA }\end{array}$ & $\mathrm{N}$ & 3000 & $\mathrm{~N}$ & $\mathrm{~N}$ & UNDER 2000 & $\mathrm{~N}$ \\
\hline LISTYA & $\mathrm{N}$ & 3000 & $\mathrm{~N}$ & $\mathrm{~N}$ & $\begin{array}{c}\text { UNIVERSIT } \\
\mathrm{Y}\end{array}$ & $\mathrm{Y}$ \\
\hline MEICY & $\mathrm{Y}$ & UNDER 2000 & $\mathrm{~N}$ & $\mathrm{Y}$ & 2000 & $\mathrm{Y}$ \\
\hline $\begin{array}{l}\text { MICHELL } \\
\text { E }\end{array}$ & $\mathrm{N}$ & UNDER 2000 & $\mathrm{~N}$ & Y & UNDER 2000 & Y \\
\hline $\begin{array}{l}\text { NATHANI } \\
\text { A }\end{array}$ & $\mathrm{N}$ & 5000 & Y & $\mathrm{N}$ & 5000 & $\mathrm{Y}$ \\
\hline SONIA & $\mathrm{N}$ & UNDER 2000 & $\mathrm{~N}$ & $\mathrm{~N}$ & UNDER 2000 & $\mathrm{Y}$ \\
\hline ADRIAN & $\mathrm{Y}$ & 3000 & $\mathrm{~N}$ & $\mathrm{~N}$ & 3000 & $\mathrm{Y}$ \\
\hline DHARMA & $\mathrm{N}$ & UNDER 2000 & $\mathrm{~N}$ & $\mathrm{Y}$ & UNDER 2000 & $\mathrm{~N}$ \\
\hline ELTON & $\mathrm{N}$ & UNDER 2000 & $\mathrm{~N}$ & $\mathrm{Y}$ & UNDER 2000 & $\mathrm{Y}$ \\
\hline
\end{tabular}




\begin{tabular}{|c|c|c|c|c|c|c|}
\hline JAMES & Y & $\begin{array}{c}\text { UNIVERSIT } \\
\mathrm{Y}\end{array}$ & Y & $\mathrm{N}$ & $\begin{array}{c}\text { UNIVERSIT } \\
\mathrm{Y}\end{array}$ & Y \\
\hline JORDAN & $\mathrm{Y}$ & 2000 & $\mathrm{~N}$ & $\mathrm{~N}$ & UNDER 2000 & $\mathrm{Y}$ \\
\hline JUNKO & $\mathrm{N}$ & 2000 & $\mathrm{~N}$ & $\mathrm{Y}$ & UNDER 2000 & $\mathrm{Y}$ \\
\hline KEVIN & $\mathrm{N}$ & 5000 & Y & Y & $\begin{array}{c}\text { UNIVERSIT } \\
\mathrm{Y}\end{array}$ & Y \\
\hline KWAN & $\mathrm{N}$ & 3000 & $\mathrm{~N}$ & $\mathrm{Y}$ & 3000 & $\mathrm{Y}$ \\
\hline $\mathrm{NICO}$ & $\mathrm{N}$ & 3000 & $\mathrm{~N}$ & $\mathrm{Y}$ & 3000 & $\mathrm{~N}$ \\
\hline ROBBY & $\mathrm{N}$ & 5000 & $\mathrm{~N}$ & $\mathrm{~N}$ & $\begin{array}{c}\text { UNIVERSIT } \\
\mathrm{Y}\end{array}$ & Y \\
\hline TIMOTHY & $\mathrm{Y}$ & 2000 & $\mathrm{~N}$ & $\mathrm{~N}$ & 5000 & $\mathrm{~N}$ \\
\hline YOSUA & $\mathrm{N}$ & 3000 & $\mathrm{~N}$ & $\mathrm{~N}$ & UNDER 2000 & $\mathrm{Y}$ \\
\hline TOTAL & $9(37.5 \%)$ & $15(62.5 \%)$ & $4(15 \%)$ & $12(50 \%)$ & $13(54 \%)$ & $20(85 \%)$ \\
\hline
\end{tabular}

From the table, it could be seen that there was $37.5 \%$ or 9 students increase on the use of Adjective-Noun combination and $50 \%$ or 12 students increase on the use of Adverb-Verb combination on their writing results. However, the writer found a fact that showed a decrease in numbers of collocation (Adjective-Noun combination) produced by the students in Week One. At Pre-Test students could produce 100 collocations in total but at Post Test students could only produce 90 collocations in total. This result proved that in productive skill such as writing, there were other aspects to be considered they were the student's needs and purposes in writing or in other word, the students' freedom to choose what collocation they wanted to use. An improvement on the use of other lexical phrases was found in students' writing from 4 students $(15 \%)$ in week one to 20 students $(85 \%)$ in week two.

\section{Based on the Teacher Journal and Questionnaire}

From the teacher's journal, the writer found that Lexical-Based Approach in teaching collocation has given significant improvement for some students especially on the use of correct collocation or lexical phrases in their writing assignment. It is proved by the increase in number from 4 students or $15 \%$ to 16 students or $85 \%$ in their ability to produce correct lexical phrases in their writing. Other evidence shows there was an increase in students' enthusiasm toward this teaching technique in week two. 
Furthermore, there was still one problem faced by the students dealing with their lack of time to do their homework which is filling in their lexical notebook. Most students around $85 \%$ hardly had enough time to do it since they were too busy with their tight schedule of extra private lessons after school.

Finally, the researcher concluded that despite all the problems faced by the students, there was a positive feedback from the questionnaires and informal interviews which said that they had got an increase in their vocabulary mastery especially their collocational competence either identifying them on the reading passage or producing them in their writing assignment.

\section{Discussion}

The result of this study was to answer the first research question that said, “Could Lexical-Based Approach used in Made Frida Yulia's Vocabulary: LexicallyBased Second Thousand Words of General Service List book improve the students' collocation production?" The answers were yes and no. Yes, since the data showed an increase in number of students using other lexical phrases from 4 students (15\%) in week one to 20 students $(85 \%)$ in week two. No, since there were two different aspects between students' competence in identifying collocation and their production in writing. It was found that in production skill such as writing, the students had a freedom to choose whatever collocation to be used, depended on their needs and purposes in writing. It was proved by the decrease in number from 100 collocations (Adjective-Noun combination) at Pre-Test to 90 collocations at Post Test.

The second research question that said, "Which collocation improved most Adjective-Noun or Adverb-Verb combination? The answer was Adverb-Verb combination around 12 students (50\%) increase or 10 collocations at Pre-Test to 24 collocations at Post Test. The third research question, "What are the students' perceptions about the teaching technique and the materials?" The answers were varied some students said that the materials contained too many difficult vocabulary while others said that they could follow the reading passages well. For teaching 
techniques, some said that they needed longer time using this technique; others said that step by step and bilingual explanation would give more benefits for the students; and finally $85 \%$ or 18 students said that they only had limited time to do the homework that was filling in their lexical notebook at home. However, due to their tight schedule of extra private lessons after school, it seemed that taking note for new words or collocation was not their habit and it was hard to start it from.

\section{Conclusion}

In this study, the writer had undergone a reflective study by comparing the frequency of students' collocation production in their written discourse between PrePost Test at Gloria Senior High School students Grade Ten to see whether LexicalBased Approach used in Made Frida Yulia's Vocabulary: Lexically-Based Second Thousand Words of General Service List book could increase the frequency of students' collocation production in their writing assignments.

The result was true in perspective that there were two different aspects of receptive and productive skills that both needed to be observed. The writer found that even the students were aware of collocation in the reading passages they read, they still needed time to make those collocation stored in their mental lexicon so that they might be able to produce them in their writing. In other word, students needed more time so that they could memorize the new collocation before able to produce them in writing. From the data collected, there was an increase in number of students using other lexical phrases from 4 students (15\%) in week one to 20 students $(85 \%)$ in week two. There was an increase of Adverb-Verb combination from 10 collocations at Pre-Test to 24 collocations at Post Test. However, it was also found a decrease in numbers of frequency from 100 collocations of AdjectiveNoun combination at Pre-Test to 90 collocations at Post Test.

Based on the result of the study, the writer recommended that teachers and practitioners who want to use this Lexical-Based Approach in the future could use bilingual explanation that is needed for Indonesian students rather than monolingual explanation in English, try to create a good note taking habit for lexical phrases as 
soon as possible, and use vivid pictures or audio visuals to kill the boredom of the students. Finally, the writer suggested that future study should observe both receptive and productive skills of the students that is very important to see the correlation between them and the effect on time needed by the students during the process.

For students who had problems in collocation, this Lexical-Based Approach as used in Made Frida Yulia's Vocabulary: Lexically-Based Second Thousand Words of General Service List book might improve the awareness toward lexical phrases, chunks and collocations. However, the writer suggested that making a habit to take note on every lexical phrases, chunks or collocations that the students might meet in the reading passages should be started as soon as possible.

\section{References}

Brown, A. 1987. Principles of Language Learning and Teaching. Prentice Hall, Englewood Cliffs. Cambridge IGCSE syllabus taken from www.cie.org.uk

Cowie, A.P. (Eds.). 1988. Stable and creative aspects of vocabulary use. In R. Carter \& M. McCarthy (Eds.). Vocabulary and language teaching (pp. 126-137). Longman. Harlow.

Creswell, J. W. (2003). Research design: Qualitative, Quantitative, and Mixed Method Approaches. Thousand Oaks, CA: Sage.

Dellar, H. \& Hocking, D. 2000. Innovations. Hove: LTP.

Halliday, M.A.K. \& Hasan, R. (1976). Cohesion in English. London \& New York: Long man

Harris, D. P. 1969. Testing English as a Second Language. McGrow-Hill Company.

Hollinsky et.al. (1995). Walk, Amble, Stroll, Level. I. Boston, MA: Heinte \& Heink.

Keller, E. 1979. 'Gambits: Conversational strategy signals'. Journal of Pragmatics, 3, 219-237.

Kweldju, S. 1997. The Lexically-based Language Teaching: An Alternative to English Language Teaching in Indonesia. In E. Sadtono (Ed.). The Development of TEFL in Indonesia (pp. 29-37). Penerbit IKIP Malang, Malang. 
Lewis, M. 1993. The lexical approach: The state of ELT and the way forward. Language Teaching Publications. Hove, England.

Lewis, M. 2001. Teaching Collocation, Language Teaching Publications, Thomson Heinle. UK.

Lewis, M. 2002. Implementing the lexical approach: Putting theory into practice. Language Teaching Publications. Thomson Heinle. Croatia

Lewis, M. (1997b). Pedagogical implications of the lexical approach. In J. Coady \& T. Huckin (Eds.), Second language vocabulary acquisition: A rationale for pedagogy (pp. 255-270). Cambridge University Press. Cambridge.

McCarthy, M. \& Felicity O'Dell. 2001. English Vocabulary in Use; UpperIntermediate, Cambridge University Press, Cambridge.

McCarthy, M. \& Felicity O’Dell. 2005. English Collocation in Use. Cambridge University Press, Cambridge.

Moudraia, O. 2001. Lexical approach to second language teaching. Eric Digest.FL026835.

Nattinger, J. 1980. A lexical phrase grammar for ESL. TESOL Quarterly, 14, 337344.

Nattinger, J., \& DeCarrico, J. 1992. Lexical phrases and language teaching. Oxford University Press. Oxford.

Nunan, D. 1992. Research Methods in Language Learning. Cambridge University Press, Cambridge

Pawley, A. \& Syder, F. 1983. 'Two puzzles for linguistic theory: Native-like selection and native-like fluency'. In J. Richards \& R. Schmidt (Eds.). Language and communication (pp. 191-226). Longman. London.

Ribisch, H. 2002. Lexical Notebooks. In M. Lewis (ed.), Implementing the lexical approach: Putting theory into practice. Language Teaching Publications. Thomson Heinle. Croatia.

Richards, J., \& Rodgers, T.S. (2001). Approaches and methods in language teaching: A description and analysis ( $2^{\text {nd }}$ ed.). New York: Cambridge University Press.

Richards, J. \& Rodgers, T. 2007. Approaches and methods in language teaching. Cambridge University Press, New York.

Richards, J. \& Lockhart, C. 1994. Reflective teaching in second language classrooms. Cambridge University Press, Cambridge. 
Rubin, Joan, and Thomson. I. 1994. How to be a More Successful Language Learner Autonomy. Heinle and Heinle Publishers. Boston.

Sinclair, J. M., \& Renouf, A. (Eds.). 1988. 'A lexical syllabus for language learning'. In R. Carter \& M. McCarthy (Eds.). Vocabulary and language teaching (pp. 140-158). Longman. Harlow.

Thornbury, S. 2002. How to Teach Vocabulary. Longman.

West, M. 1953. A General Service List of English Words. Longman. London.

Willis, D. 1990. The lexical syllabus: A new approach to language teaching. Collins COBUILD. London.

Wilkins, D.A. 1972. Linguistics in Language Teaching. Edward Arnold. London.

Willis, J. D. 1990. The Lexical Syllabus. Collins COBUILD. London.

Yulia, M. F. 2005. Vocabulary: Lexically-based Second Thousand Words of General Service List. Muhammadiyah University Press. Surakarta. 